Revista Ensaios, vol. 13, jul-dez de 2018. ISSN 2175-0564.

\title{
Somos deuses
}

Cláudio Gonçalves da Silva Correio ${ }^{1}$

Chegou nossa hora de parar e refletir,

Refletir sobre cada palavra e cada gesto

E seu impacto sobre nosso irmão,

Palavras e gestos que abalam o coração,

Palavras de ódio e rancor de seres insignificantes que somos,

Palavras que nos causam cortes, dores que nos leva à morte

E que muitas vezes, ferem como uma lança nosso irmão,

Cuja força, o faz cair em tristeza, solidão, depressão...

Ódio que carregamos dentro de nossa alma,

Que nos faz perder nossa calma,

Que nos faz perder a vida ao brincar com nosso próximo,

Ódio que nos tornam deuses por um instante.

Achamos então, que nos tornamos “deuses"!

E que culpamos com o sabor amargo nosso semelhante,

Que julgamos e condenamos sem dó, nem piedade.

Afinal, somos deuses de verdade!

\footnotetext{
${ }^{1}$ Universidade Federal do Maranhão (UFMA), Departamento de Biologia, Chapadinha, MA, Brasil.clagsilva@gmail.com.
} 
Revista Ensaios, vol. 13, jul-dez de 2018. ISSN 2175-0564.

Um ser (des)humano, um ser (ir)racional,

Sem palavras que mensurem o dissabor de se fazer deuses,

Condenando, matando, massacrando, torturando, oprimindo...

E ainda assim, se achar um ser eterno, divino,

Perdemos nossa essência, nosso carisma e paciência,

Uma evolução em sentido contrário, triste fim...

Daqueles que se acham superiores na raça humana,

Daqueles que trocaram o amor pelo ódio,

Daqueles que acham que viverão além da eternidade

E que não passa de um sujeito mundano.

Essa é a época que não escolhemos para viver

Mas é a que teremos para morrer,

Momento esse onde vivemos e que trocamos:

Os sonhos profícuos, pela vida infértil,

O amor verdadeiro e duradouro, pelas aventuras terrenas,

A felicidade, pela melancolia do dia a dia,

O carinho da família, pelo universo "magnífico" das drogas,

Os pensamentos positivos, por aqueles sombrios que povoam nossa mente.

Então, nossas frustrações creditamos ao outro,

Que sempre será o culpado por tudo,

Somos deuses intolerantes, imprudentes, tiranos, implacáveis...

Aliás, somos simples, não somos nada, apenas mortais! 